\title{
Synthesis and Evaluation of Insecticidal Activity of Bis-Semicarbazones and Bis-(5-Aryl Substituted-1, 3, 4-0xadiazole)
}

\author{
Veerabhadraswamy Maruthyunjayaa ${ }^{1, *}$, Bhimashankar B Molkere ${ }^{1}$, Prashantha Karunakar $^{2}$ \\ ${ }^{1}$ Department of Science and Humanities, PES University, Bengaluru, Karnataka, INDIA. \\ 2Department of Biotechnology, PES University, Bengaluru, Karnataka, INDIA.
}

\begin{abstract}
Background: Various substituted semicarbazones and oxadiazols have been widely investigated for their insecticidal and pharmacological activities. Heterocyclic analogs of these types were extensively studied for their biological activities. In this study insecticidal activity of semicarbazones and oxadiaziole created our interest to prepare and screen the activity. Objectives: To prepare a series of substituted semicarbazones and oxadiazoles, with an observation to subjecting them for insecticidal and pharmacological screening. Methodology: An oxalic acid dicarbohydrazide compound was prepared by a mixture of diethyl oxalate (0.1 mole), hydrazine hydrate (99\%) (0.2 mole) and 2-3 drops of Conc. $\mathrm{HCl}$ in absolute ethanol. Resulted compound was reflexed with different substituted aldehyde (0.05 moles) with addition of 1-2 drops of Conc. $\mathrm{HCl}$ in an absolute ethanol to acquired bis-semicarbazones. Derived bis-semicarbazones were subjected for oxidation using ferrichloride $(20 \mathrm{mg})$ and acetic acid $(8 \mathrm{~mL})$ to obtain oxadiazole derivatives. Results: The compounds $2 \mathrm{c}-\mathrm{d}$ and $3 \mathrm{a}$ showed high percentage of mortality in an insecticidal activity. Compounds $3 \mathrm{a}$ and $3 \mathrm{~b}$ exhibited high anti-bacterial activity against Kallipsi calla, in case of Escherichia coli the compound $2 \mathrm{~d}, 3 \mathrm{a}, 3 \mathrm{c}$ and $3 \mathrm{~d}$ shows maximum activity. Compounds $3 \mathrm{a}$ and $3 \mathrm{~d}$ showed high anti-fungal activity against $A$. nigar and $3 c$ against $A$. flavous. The compounds 2a, 2b, 3c have shown good anti-inflammatory activity. Compound $3 \mathrm{~d}$ showed a competitive inhibitory activity and act as lead molecule towards the drug designing. Conclusion: The present study exposed that the synthesized compounds exhibit significant insecticidal, anti-bacterial, anti-fungal, anti-inflammatory activity and act as lead molecule towards the drug designing.
\end{abstract}

Key words: Semicarbazone, Oxadiazole, Insecticidal activity, Biological activity, AutoDock.

\section{INTRODUCTION}

The semicarbazone and thio-semicarbazone derivatives have acknowledged significant attention from pharmaceutical industry due to their wide spectrum of their potential activities such as biological activities, anticonvulsant, anti-oxidant, anti-microbial activities, anti-viral, anti-HIV, anti-bacterial activities and anticancer. ${ }^{1,2}$ In the recent years, some workers reviewed the bioactivity of semicarbazones exhibited anticonvulsant, anti-tubercular and aryl semicarbazones has been recognized as structurally novel class of compounds with remarkable anti-epileptic activity, anti-convulsant activity, with one of the important parameters for anti-convulsant activity. ${ }^{3}$ The Present technology motivate and its derivatives embrace a vital session of biologically and pharmacologically active heterocyclic compounds such as anti-bacterial, ${ }^{4}$ anti-fungal, ${ }^{5,6}$ anti-inflammatory ${ }^{7}$ and anti-convulsant activities.

The oxadiazole derivatives have its place in an important group of heterocyclic compounds for developing pharmaceutically significant molecules 1, 3, 4-oxadiazole derivatives have played a vital role in the medicinal chemistry. Abundant compounds with oxadiazole nucleus
Submission Date: 18-02-2019; Revision Date: 13-06-2019; Accepted Date: 28-06-2019

DOI: 10.5530/ijper.53.3s.115 Correspondence: Dr. Veerabhadraswamy Maruthyunjaya, Department of Science and Humanities, PES University, BSK III Stage, Bengaluru560085, Karnataka, INDIA Phone: +919241503423 E-mail: vbs@pes.edu

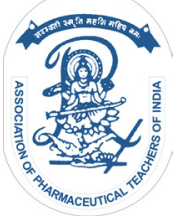

www.ijper.org 
used for anti-bacterial, anti-HIV, anti-fungal, antitubercular, veridical, anti-malarial, insecticidal, herbicidal, ant-imicrobial, anti-viral, anti-parkinsonian, anti-TB, anti-proliferative, anti-inflammatory and analgesic, muscle relaxant, anti-convulsant, sedative, hypnotic, anti-cancerand inhibition of lipid per-oxidation, hypertensive activities. Collected works on synthesis of oxa diazoles contain bromine oxidation of a semicarbazide derivative and the cyclo-desulfurization of acylthiosemicarbazide derivatives in solution using $\mathrm{I}_{2} / \mathrm{NaOH}$ or 1,3-dicyclohexylcarbodimide (DCC) as well as mercury (II) acetate $\left(\mathrm{Hg}(\mathrm{OAc})_{2}\right)$ or yellow mercury (II) oxide $\mathrm{HgO}^{8-10}$ All these methods are usually carried out in different synthetic steps that require very dangerous reagents and produce undesirable mercury byproduct, at this time the insects and pests are getting more unaffected owed to use of insecticides.

In view of these observations, an attempt has been made to develop more dominant compounds with smaller amount of side effect and bio-products, we hereby report the synthesis, characterization and screened for biological activities of new substituted derivatives of a novel series of bis-semicarbazones and bis-(5-aryl substituted- 1, 3, 4-Oxadiazole) derivatives, as improved and potent insecticidal, anti-bacterial, anti-inflammatory, anti-fungal, Molecular docking studies.

\section{MATERIALS AND METHODS}

The homogeneity of all the newly synthesized compounds was routinely checked by thin layer chromatography (TLC) on silica gel G plates (silica gel 60F254) and spots were located by using iodine chamber. The IR spectra (in $\mathrm{KBr}$ disks) were recorded on Perkin Elmer and the characteristic bands obtained at the wave numbers are specific to the functional group of the molecular structure. ${ }^{11}{ }^{1} \mathrm{H}-\mathrm{NMR}$ spectra were recorded by an instrument using DMSO- $\mathrm{d}_{6}$ as solvent and tetramethylsilane (TMS) as internal reference standard. All chemical shift values were recorded at $\delta(\mathrm{ppm})$. Commercial grade solvents and reagents were used without further purification. The chemicals used in the synthesis of new compounds are diethyl oxalate, hydrazine hydrate, Ethanol, AR grade, Hydrochloric acid and so on.

The reaction scheme employed for the synthesis of compounds $\mathrm{N}^{\prime 1}, \mathrm{~N}^{\prime 2}$-bis[phenylmethylidene]ethanedihydrazide (2a), $\quad \mathrm{N}^{\prime 1}, \mathrm{~N}^{\prime 2}$-bis[(2-hydroxyphenyl)methylidene] ethanedihydrazide (2b), $\mathrm{N}^{\prime 1}, \mathrm{~N}^{\prime 2}$ - bis [(4-methoxyphenyl) methylidene] ethanedihydrazide (2c), $\mathrm{N}^{1}, \mathrm{~N}^{\prime 2}$ - bis [(4-hydroxy-3-methoxyphenyl) methylidene] ethanedihydrazide (2d), 5,5'-diphenyl-2, 2'-bi-1,3,4-oxadiazole (3a),2,2'-(2, 2'-bi-1,3,4-oxadiazole-5, 5'-diyl) diphenol (3b), 5,5'-bis(4-methoxyphenyl)-2,2'-bi-1,3,4-oxadiazole (3c), 4,4'-2,2'-bi-1,3,4-oxadiazole-5,5'-diyl)bis(2-methoxyphenol) (3d) are given in Figure 1-3 and the substituents and molecular formula of semicarbazones and oxadiazoles are summarized in Table 1. An intermediate compound oxalic acid dicarbohydrazidesis refluxed with substituted aldehyde with the addition of 1-2 drops of $\mathrm{HCl}$ in absolute ethanol media yielded bis-semicarbazones (2a-d) and the process of an oxidation of semicarbazones with ferrichloride gives bis-(5-aryl substituted - 1, 3, 4-Oxadiazole) (3a-d). The structures of the newly synthesized compounds are established by FT-IR and NMR spectra respectively.

\section{Experimental Section}

\section{General procedure for the synthesis of oxalic acid dicarbohydrazide, bis-semicarbazonesandbis-(5-

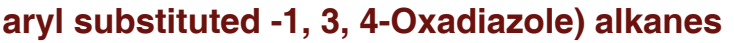

\section{Oxalic acid dicarbohydrazide}

An intermediate oxalic acid dicarbohydrazide compound (1) was prepared by refluxing the mixture of the diethyl oxalate (0.1 moles), hydrazine hydrate ( $99 \%)$ ( 0.2 mole) with 2-3 drop of concentrated hydrochloric acid $(\mathrm{HCl})$ in a round bottom flask containing absolute ethanol $(50 \mathrm{~mL})$ for a period of 8-9 $\mathrm{hr}$ and cooled to room temperature. The resulted compound was filtered, dried and crystallized from Dimethylformamide DMF.

\section{Bis-semicarbazones}

The mixture of intermediate oxalic acid dicarbohydrazides (0.025 mole)(1), substituted aldehyde (0.05 mile) and 1-2 drops of conc. $\mathrm{HCl}$ in absolute ethanol $(20-30 \mathrm{~mL})$ were refluxed for 7-8 hr, cooled to room temperature. Thus gained product was filtered, washed, dried and crystallized from D.M.F to yield bissemicarbazones compounds (2a-d).

\begin{tabular}{|c|c|c|c|}
\multicolumn{5}{|c|}{ Table 1: Substituent and Molecular formula of semi- } \\
carbazones and Oxadiazoles. \\
SI.No. & Compounds & Substituent & $\begin{array}{c}\text { Molecular } \\
\text { Formula }\end{array}$ \\
\hline 1 & $2 a$ & $-\mathrm{C}_{6} \mathrm{H}_{5}$ & $\mathrm{C}_{16} \mathrm{H}_{14} \mathrm{~N}_{4} \mathrm{O}_{2}$ \\
\hline 2 & $2 b$ & $-2-\mathrm{OH}_{-}-\mathrm{C}_{6} \mathrm{H}_{4}$ & $\mathrm{C}_{16} \mathrm{H}_{14} \mathrm{~N}_{4} \mathrm{O}_{4}$ \\
\hline 3 & $2 \mathrm{c}$ & $-4-\mathrm{OCH}_{3}-\mathrm{C}_{6} \mathrm{H}_{4}$ & $\mathrm{C}_{18} \mathrm{H}_{18} \mathrm{~N}_{4} \mathrm{O}_{4}$ \\
\hline 4 & $2 \mathrm{~d}$ & $-3-\mathrm{OCH}_{3}-4-\mathrm{OH}-\mathrm{C}_{6} \mathrm{H}_{3}$ & $\mathrm{C}_{18} \mathrm{H}_{18} \mathrm{~N}_{4} \mathrm{O}_{6}$ \\
\hline 5 & $3 a$ & $-\mathrm{C}_{6} \mathrm{H}_{5}$ & $\mathrm{C}_{16} \mathrm{H}_{10} \mathrm{~N}_{4} \mathrm{O}_{2}$ \\
\hline 6 & $3 \mathrm{~b}$ & $-2-\mathrm{OH}_{-}-\mathrm{C}_{6} \mathrm{H}_{4}$ & $\mathrm{C}_{16} \mathrm{H}_{10} \mathrm{~N}_{4} \mathrm{O}_{4}$ \\
\hline 7 & $3 \mathrm{c}$ & $-4-\mathrm{OCH}_{3}-\mathrm{C}_{6} \mathrm{H}_{4}$ & $\mathrm{C}_{18} \mathrm{H}_{14} \mathrm{~N}_{4} \mathrm{O}_{4}$ \\
\hline 8 & $3 \mathrm{~d}$ & $-3-\mathrm{OCH}_{3}-4-\mathrm{OH}_{-}-\mathrm{C}_{6} \mathrm{H}_{3}$ & $\mathrm{C}_{18} \mathrm{H}_{14} \mathrm{~N}_{4} \mathrm{O}_{6}$ \\
\hline
\end{tabular}




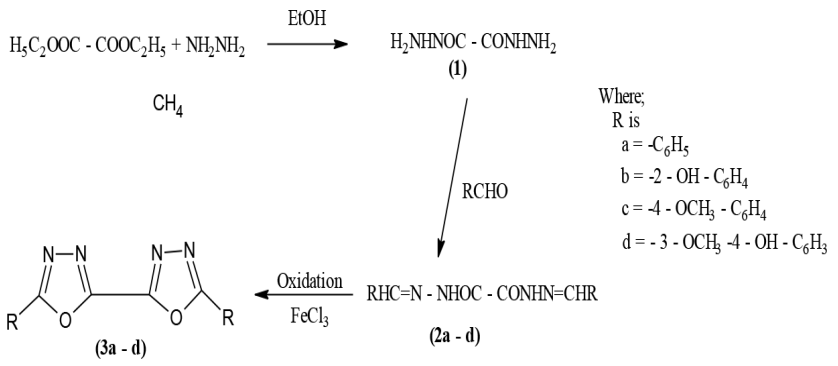

Figure 1: Synthetic route for the compounds $2 a-d$ and $3 a-d$.

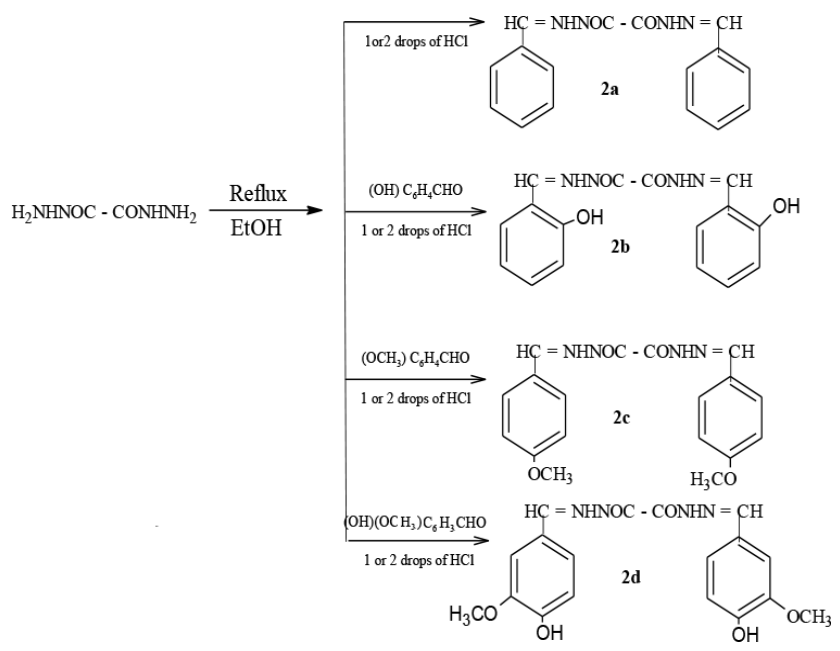

Figure 2: Synthetic route for the compounds 2a-d. Semicarbazones.

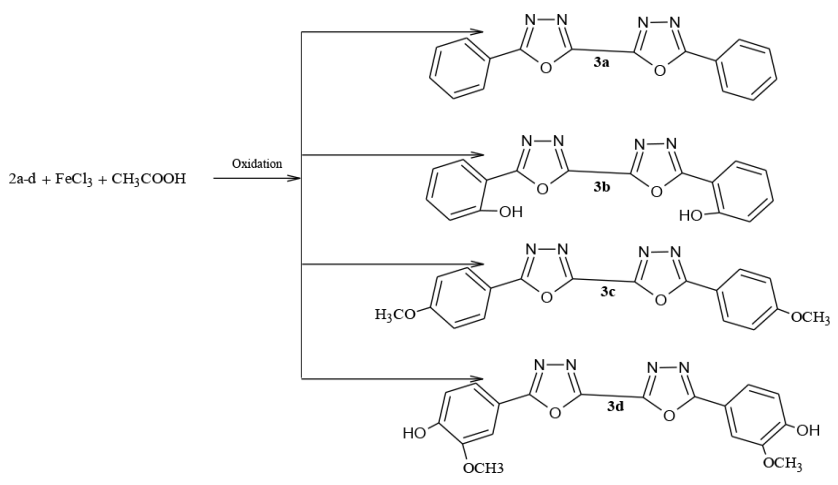

Figure 3: Synthetic route for the compounds 3a-d.Oxadiazoles.

\section{Bis-(5-aryl substituted -1, 3, 4-Oxadiazole) alkanes}

A mixture of bis-semicarbazones (2a-d) (0.002 mole), Ferrichloride $(20 \mathrm{mg})$ and acetic acid $(8 \mathrm{~mL})$ were stirred for one hour, solution was poured over the water (15-20 mL) and left undisturbed for a period of $72 \mathrm{hr}$, the resulted solid product was filtered, washed with water, dried and crystallized from Dimethylforamide (D.M.F) to get compounds (3a-d).

\section{Compound 2a}

$\mathrm{N}^{11}, \mathrm{~N}^{22}$-bis [phenylmethylidene]ethanedihydrazide]. IR $\left(\nu \mathrm{cm}^{-1}, \mathrm{KBr}\right): 3247.9$ (NH, m, stretch), $3055.0(\mathrm{CH}, \mathrm{s}$, stretch), 1959.5, 1658.7(C=O,s, stretch), 1234.4 (CO, s, stretch), 964.3, 879.5, 817.8, 756.0, 686.6 and 540.0(C$\mathrm{H}, \mathrm{s}$, aromatics), ${ }^{1} \mathrm{H}-\mathrm{NMR}\left(\mathrm{DMSO}-\mathrm{d}_{6}\right) \delta(\mathrm{ppm}): 7.3$ - 7.6 (m, 10H, ArH), 8.0 (bs, 2H, NH $)$ ), 8.1(s, 2H, CH), Molecular Formula; $\mathrm{C}_{16} \mathrm{H}_{14} \mathrm{~N}_{4} \mathrm{O}_{2}$, Formula Weight; 294.30796, Anal. Cald for $\mathrm{C}_{16} \mathrm{H}_{14} \mathrm{~N}_{4} \mathrm{O}_{2}$ : C, 65.30; H, 4.79; N, 19.04; $\mathrm{O}, 10.87$. Density $\left(\mathrm{g} / \mathrm{cm}^{3}\right) ; 1.19 \pm 0.1$ and Polarizability $\left(\mathrm{cm}^{3}\right) ; 33.73 \pm 0.510^{-24}$. Nominal Mass (Da); 294 .

\section{Compound 2b}

$\mathrm{N}^{\prime 1}, \mathrm{~N}^{\prime 2}$-bis [(2-hydroxyphenyl) methylidene] ethanedihydrazide.

IR $\left(v \mathrm{~cm}^{-1}, \mathrm{KBr}\right): 3155.3(\mathrm{OH}, \mathrm{m}$, stretch), 3062.7 (CH, s, stretch), 2368.4 (H-C=O, m, stretch), 1967.3, 1666.4 (C=O, s, stretch), 1257.5 (CO, s, stretch), 964.3, 871.8, 825.5, 756.0, 632.6 and 532.3 (C-H,s, aromatics), ${ }^{1} \mathrm{H}-\mathrm{NMR}$ (DMSO-d $) \delta(\mathrm{ppm}): 5.0(\mathrm{~s}, 2 \mathrm{H}, \mathrm{OH}), 6.8-7.4$ $(\mathrm{m}, 8 \mathrm{H}, \mathrm{ArH}), 8.0\left(\mathrm{bs}, 2 \mathrm{H}, \mathrm{NH}_{2}\right), 8.1(\mathrm{~s}, 2 \mathrm{H}, \mathrm{CH})$, Molecular Formula; $\mathrm{C}_{16} \mathrm{H}_{14} \mathrm{~N}_{4} \mathrm{O}_{4}$, Formula Weight; 326.30676, Anal. Cald for $\mathrm{C}_{16} \mathrm{H}_{14} \mathrm{~N}_{4} \mathrm{O}_{4}$ : C, 58.89; H, 4.32; N, 17.17; $\mathrm{O}, 19.61$. Density $\left(\mathrm{g} / \mathrm{cm}^{3}\right) ; 1.35 \pm 0.1$, Polarizability $\left(\mathrm{cm}^{3}\right) ; 34.41 \pm 0.510^{-24}$ and Nominal Mass (Da); 326.

\section{Compound 2c}

$\mathrm{N}^{\prime 1}, \mathrm{~N}^{\prime 2}$ - bis [(4-methoxyphenyl) methylidene] ethanedihydrazide.

IR $\left(\nu \mathrm{cm}^{-1}, \mathrm{KBr}\right): 3247.9$ (NH, m, stretch), 2908.5 (CH, s, stretch), 2839.0 (H-C=O, m, stretch), 1897.8, 1666.4 (C=O, s, stretch), 1303.8 (CO, s, stretch), 964.3, 817.8, 717.5, 586.3, 547.7 and 455.2 (C-H,s, aromatics), ${ }^{1} \mathrm{H}-\mathrm{NMR}$ (DMSO-d $) \delta(\mathrm{ppm}): 3.73\left(\mathrm{~s}, 6 \mathrm{H}, \mathrm{CH}_{3}\right)$, $6.8-7.5$ (m, 8H, ArH), 8.0 (bs, 2H, NH $), 8.1$ (s, 2H, CH), Molecular Formula; $\mathrm{C}_{18} \mathrm{H}_{18} \mathrm{~N}_{4} \mathrm{O}_{4}$, Formula Weight; 354.35992, Anal. Cald for $\mathrm{C}_{18} \mathrm{H}_{18} \mathrm{~N}_{4} \mathrm{O}_{4}$ : C, 61.01; H, 5.12; N, 15.81; O, 18.06. Density $\left(\mathrm{g} / \mathrm{cm}^{3}\right) ; 1.22 \pm 0.1$, Polarizability $\left(\mathrm{cm}^{3}\right) ; 38.34 \pm 0.510^{-24}$ and Nominal Mass (Da); 354.

\section{Compound 2d}

$\mathrm{N}^{11}, \mathrm{~N}^{2}$ - bis [(4-hydroxy-3-methoxyphenyl) methylidene] ethanedihydrazide.

IR $\left(\nu \mathrm{cm}^{-1}, \mathrm{KBr}\right): 3502.5(\mathrm{OH}, \mathrm{m}$, stretch), 3232.5 (NH, m, stretch), 2931.6 (CH, s, stretch), 2800.4, 2368.4 (H-C=O, m, stretch), 2044.4, 1658.7 (C=O, s, stretch), 1427.2, 1380.9, 1272.9 (CO, s, stretch), 964.3, 833.2, 740.6, 663.5, 624.9 and 532.3 (C-H,s, aromatics), ${ }^{1} \mathrm{H}-\mathrm{NMR}$ (DMSO-d $) \delta$ (ppm): 3.73 (s, 6H, CH3 ), 5.0 (s, 2H, OH), $6.7-7.0$ (m, 6H, ArH), 8.0 (bs, 2H, NH ${ }_{2}$ ), 
8.1 (s, 2H, CH), Molecular Formula; $\mathrm{C}_{18} \mathrm{H}_{18} \mathrm{~N}_{4} \mathrm{O}_{6}$, Formula Weight; 386.35872, Anal. Cald for $\mathrm{C}_{18} \mathrm{H}_{18} \mathrm{~N}_{4} \mathrm{O}_{6}$ : C, 55.96; H, 4.70; N, 14.50; O, 24.85. Density $\left(\mathrm{g} / \mathrm{cm}^{3}\right)$; $1.35 \pm 0.1$, Polarizability $\left(\mathrm{cm}^{3}\right) ; 39.02 \pm 0.510^{-24}$ and Nominal Mass (Da); 386.

\section{Compound $3 a$}

5, 5'-diphenyl-2, 2'-bi-1, 3, 4-oxadiazole.

IR $\left(\nu \mathrm{cm}^{-1}, \mathrm{KBr}\right): 3247.9(\mathrm{NH}, \mathrm{m}$, stretch), $2360.7(\mathrm{C}-\mathrm{H}$, s, aromatics), $1658.7(\mathrm{C}=\mathrm{N}), 1527.5(\mathrm{C}=\mathrm{C}$, aromatic), 1450.4, 1357.8 (C-N), 1234.4, 1195.8 (C-O-C), 1049.2, 964.3, 879.5, 817.8, 686.6 and 540.0 (C-H,s, aromatics), ${ }^{1} \mathrm{H}-\mathrm{NMR}\left(\mathrm{DMSO}-\mathrm{d}_{6}\right) \delta(\mathrm{ppm}): 7.22-7.48(\mathrm{~m}, 10 \mathrm{H}$, ArH), Molecular Formula; $\mathrm{C}_{16} \mathrm{H}_{10} \mathrm{~N}_{4} \mathrm{O}_{2}$, Formula Weight; 290.2762, Anal. Cald for $\mathrm{C}_{16} \mathrm{H}_{10} \mathrm{~N}_{4} \mathrm{O}_{2}$ : C, 66.20; $\mathrm{H}, 3.47$; N, 19.30; O, 11.02. Density $\left(\mathrm{g} / \mathrm{cm}^{3}\right) ; 1.297 \pm$ 0.06 , Polarizability $\left(\mathrm{cm}^{3}\right) ; 30.52 \pm 0.510^{-24}$ and Nominal Mass (Da); 290.

\section{Compound $3 b$}

2, 2'- (2, 2'-bi-1,3,4-oxadiazole-5, 5'-diyl) diphenol.

IR $\left(\nu \mathrm{cm}^{-1}, \mathrm{KBr}\right): 3201.6(\mathrm{NH}, \mathrm{m}$, stretch), 3062.7, 2368.4 (C-H, s, aromatics), $1666.4(\mathrm{C}=\mathrm{N}), 1535.2(\mathrm{C}=\mathrm{C}$, aromatic), 1458.1, 1357.8 (C-N), 1257.5, 1218.9 (C-O-C), $1056.9,964.3,871.8,825.5,756.0,632.6$ and $532.3(\mathrm{C}-\mathrm{H}, \mathrm{s}$, aromatics), ${ }^{1} \mathrm{H}-\mathrm{NMR}$ (DMSO-d $) \delta(\mathrm{ppm}): 5.0$ (s, 2H, $\mathrm{OH}), 6.88-7.31$ (m, 8H, ArH), Molecular Formula; $\mathrm{C}_{16} \mathrm{H}_{10} \mathrm{~N}_{4} \mathrm{O}_{4}$, Formula Weight; 322.275, Anal. Cald for $\mathrm{C}_{16} \mathrm{H}_{10} \mathrm{~N}_{4} \mathrm{O}_{2}: \mathrm{C}, 66.20 ; \mathrm{H}, 3.47 ; \mathrm{N}, 19.30 ; \mathrm{O}, 11.02$. Density $\left(\mathrm{g} / \mathrm{cm}^{3}\right) ; 1.297 \pm 0.06$, Polarizability $\left(\mathrm{cm}^{3}\right) ; 30.52 \pm 0.5$ $10^{-24}$ and Nominal Mass (Da); 290.

\section{Compound 3c}

5, 5'-bis (4-methoxyphenyl)-2, 2'-bi-1, 3, 4-oxadiazole. IR $\left(\nu \mathrm{cm}^{-1}, \mathrm{KBr}\right): 3247.9(\mathrm{NH}, \mathrm{m}$, stretch), 2839.0(C$\mathrm{H}, \mathrm{s}$, aromatics), 1897.8, $1658.7(\mathrm{C}=\mathrm{N}), 1604.7,1504.4$ (C=C, aromatic), $1365.5(\mathrm{C}-\mathrm{N}), 1303.8,1249.8$ (C-O-C), 1026.1, 964.3, 817.8, 717.5, 586.3 and 547.7 (C-H,s, aromatics), ${ }^{1} \mathrm{H}-\mathrm{NMR}$ (DMSO-d $) \delta$ (ppm): 3.73 (s, 6H, $\left.\mathrm{CH}_{3}\right), 6.83-7.31$ (m, 8H, ArH), Molecular Formula; $\mathrm{C}_{18} \mathrm{H}_{14} \mathrm{~N}_{4} \mathrm{O}_{4}$, Formula Weight; 350.32816, Anal. Cald for $\mathrm{C}_{18} \mathrm{H}_{14} \mathrm{~N}_{4} \mathrm{O}_{4}$ : C, 61.71; H, 4.03; N, 15.99; O, 18.27. Density $\left(\mathrm{g} / \mathrm{cm}^{3}\right) ; 1.289 \pm 0.06$, Polarizability $\left(\mathrm{cm}^{3}\right)$; $35.81 \pm 0.510^{-24}$ and Nominal Mass (Da); 350 .

\section{Compound 3d}

4, 4'-2, 2'-bi-1, 3, 4-oxadiazole-5, 5'-diyl) bis (2-methoxyphenol).

IR ( $\left.v \mathrm{~cm}^{-1}, \mathrm{KBr}\right): 3502.5(\mathrm{OH}, \mathrm{m}$, stretch), $3232.5(\mathrm{NH}$, m, stretch), 2931.6, 2800.4, 2368.4 (C-H, s, aromatics), 2044.4, $1658.7(\mathrm{C}=\mathrm{N}), 1596.9,1512.1(\mathrm{C}=\mathrm{C}$, aromatic), 1427.2, 1380.9 (C-N), 1272.9 (C-O-C), 1211.2, 1103.2, 1026.1, 964.3, 833.2, 740.6, 663.5, 624.9 and 532.3
(C-H,s, aromatics), ${ }^{1} \mathrm{H}-\mathrm{NMR}$ (DMSO-d $\left.\mathrm{d}_{6}\right) \delta(\mathrm{ppm})$ : $3.73\left(\mathrm{~s}, 6 \mathrm{H}, \mathrm{CH}_{3}\right), 5.0$ (s, $\left.2 \mathrm{H}, \mathrm{ArOH}\right), 6.68-6.87$ (m, 6H, ArH), Molecular Formula; $\mathrm{C}_{18} \mathrm{H}_{14} \mathrm{~N}_{4} \mathrm{O}_{6}$, Formula Weight; 382.32696, Anal. Cald for $\mathrm{C}_{18} \mathrm{H}_{14} \mathrm{~N}_{4} \mathrm{O}_{6}$ : C, 56.55; $\mathrm{H}, 3.69$; N, 14.65; O, 25.11. Density $\left(\mathrm{g} / \mathrm{cm}^{3}\right) ; 1.423 \pm$ 0.06 , Polarizability $\left(\mathrm{cm}^{3}\right) ; 37.30 \pm 0.510^{-24}$ and Nominal Mass (Da); 382.

\section{Insecticidal activity}

The activity was studied into three general classes as a stomach poison, contact poison and untreated check. ${ }^{12}$ About $25 \mathrm{mg}$ of synthesized compounds were dissolved in a minimum amount of acetone and 4-5 drops of Tween- 80 were added as an emulsifying agent and diluted to $50 \mathrm{~mL}$ into a volumetric flask separately. For stomach poison, the prepared solutions were sprayed on the red gram by using a micro sprayer (i.e. atomizer). On the other hand the larvae of Heliothis armigera were taken. These (24 in number) were placed one in each compartment of the tray. The sprayed pods were then fed and observation of the percentage of mortality recorded in 24, 48 and $72 \mathrm{hr}$. For contact poison, the larvae of Heliothis armigera were placed one in each compartment of the tray which was half filled with diet. The solutions above prepared were sprayed directly on the larval body by using atomizer and the percentage of mortality was recorded after 24, 48 and $72 \mathrm{hr}$ as shown in Table 2. These stomach and contact poisons are observed and verified against untreated check by placing the larvae in each compartment of the tray. The red gram pods are fed without any treatment and were kept for observation. The mortality was observed after 24,48 and $72 \mathrm{hr}$ were as same as the test compound observed. Bio-efficacy testing of semicarbazones (2a-d) and ox adiazoles (3a-d).

\section{Anti-bacterial activity}

The Cup-Plate Method given by Cruickshank et al. ${ }^{13}$ Nutrient agar was poured onto the sterilized petri dishes (20-25 mL each petri dish). The poured material was allowed to set for $2 \mathrm{~h}$ and thereafter the "CUPS" $(6 \mathrm{~mm}$ diameter) were made by punching into the agar surface with a sterile corn borer and scooping out the punched part of the agar. To these cups the test compound solution was added with the help of sterile syringe. The plates were incubated at $37^{\circ} \mathrm{C}$ for overnight and the results pertaining to zone of inhibition developed were noted. The zone of inhibition developed. A (1\% $\mathrm{v} / \mathrm{v}$ ) solution of Gentamycin was used as standard and solvent control (DMSO) was also used to know the activity of the solvent. The above said standard drugs 
were also screened under similar conditions for comparison.

\section{Anti-fungal activity}

The spore suspension of each test organism was added to sterilize the sabouraud dextrose agar medium at $40-50^{\circ} \mathrm{C}$ by thorough shaking. The petri dishes were seeded with the mixture and the paper discs of the methanol solution of compounds and the reference antibiotic as the control was placed in the same manner as in anti-bacterial activity determination. ${ }^{14,15}$ These petri dishes were incubated for $24 \mathrm{hr}$ at room temperature. The zone of inhibition developed of any, was then accurately measured and recorded.

\section{Anti-inflammatory activity}

Albino rats of either sex weighing between 120-150g were selected; the animals were fasted for $24 \mathrm{hr}$ with water ad libitum. Animals were marked on their hind paws (right and left) just beyond the tibio-tarsal to ensure constant dipping in the mercury column up to the fixed mark. The test doses $(25 \mathrm{mg} / \mathrm{kg})$ were prepared in Tween-80 and suspended in water. After $30 \mathrm{~min}$, $(0.1 \mathrm{~mL}$ of $1 \% \mathrm{v} / \mathrm{v})$ formalin solution was injected into the plantar region of the left paw of all experimental animals. The right non-inflamed paw served as reference for comparison. At the end of $5 \mathrm{hr}$, after formalin injection the paw volume of both legs of all the experimental animals was measured with the help of the plethysmograph. In the same way test group were used for evaluating the anti-inflammatory activity of the respective test compounds. The percentage inhibitions of the inflammation by the drug treated animals were recorded using the formula. Percentage inhibition $=100(1-\mathrm{T} / \mathrm{C})$, Where $\mathrm{T}$ and $\mathrm{C}$ are volumes of edema of drugs treated and control group respectively.

The synthesis compounds were tested for anti-inflammatory activity in-vitro against albino rats and compared with that of standard drug Dichlophenac sodium.

\section{Protein and ligand structure preparation}

The X-Ray Crystallographic structures of the $1.6 \AA$ models of crystal structure of the complex formed between Russell's Viper Phospholipase A2 and an Antiinflammatory agent Diclofenac (PDB: 2B17) were obtained from the protein databank (www.pdb.org). Topology file and other force field parameters were generated for all Semicarbazones andoxadiazolederivatives using the PRODRG program. Flexible torsions were defined using AUTOTORS. The docking site for semicarbazones and oxadiazolederivatives on 2B17 was defined at the position of the co-crystallized ligand by using PyRX 0.8 interface with grid box size of 52 x 49 x 58 spacing of 0.375 , grid center 48.098, 32.710, 6.880 and assigned 3 Degrees of Freedom. The Lamarckian Genetic Algorithm (LGA) ${ }^{16}$ was employed with the population size of 150 individuals, maximum number of generations and energy evaluations of 27,000 and 2.5 million respectively. From the estimated free energy of ligand binding $(\Delta G)$, the inhibition constant $\left(K_{i}\right)$ for each ligand was calculated. Only the best pose (the one with the lowest binding energy) was considered for the ligand. The best conformation was analyzed for protein, semicarbazones and oxadiazole derivatives interaction using Ligplot+. PyMOL ${ }^{17,18}$ was used for docking conformation representation.

\section{RESULTS AND DISCUSSION}

The compounds $\mathrm{N}^{\prime 1}, \mathrm{~N}^{2}$-bis [phenylmethylidene] ethanedihydrazide (2a), $\quad \mathrm{N}^{\prime 1}, \mathrm{~N}^{\prime 2}$-bis[(2-hydroxyphenyl) methylidene] ethanedihydrazide (2b), $\mathrm{N}^{11}, \mathrm{~N}^{2}$ - bis [(4-methoxyphenyl) methylidene] ethanedihydrazide (2c), $\mathrm{N}^{1}, \mathrm{~N}^{\prime 2}$ - bis [(4-hydroxy-3-methoxyphenyl) methylidene] ethanedihydrazide (2d), 5,5'-diphenyl-2,2'-bi-1,3,4oxadiazole (3a),2,2'-(2, 2'-bi-1,3,4-oxadiazole-5, 5'-diyl) diphenol (3b), 5,5'-bis(4-methoxyphenyl)-2,2'-bi-1,3,4oxadiazole (3c), 4,4'-(2,2'-bi-1,3,4-oxadiazole-5,5'-diyl) bis (2-methoxyphenol) (3d) were synthesized by using reflux method. The synthetic routes of these compounds are illustrated in the Figures. The chemical structures of these were found to be in accordance with their IR and ${ }^{1} \mathrm{H}-\mathrm{NMR}$ Spectra; detail spectral data are summarized in the material and methods section. The IR Spectrum of $2 \mathrm{a}-\mathrm{d}$ and $3 \mathrm{a}-\mathrm{d}$ were measured by using the powdered potassium bromide as background correction. The IR Spectrum of compound 2a showed wave numbers $3247.9 \mathrm{~cm}^{-1}$ corresponding to the $\mathrm{NH}$ medium stretch, $3055.0 \mathrm{~cm}^{-1}$ corresponding to $\mathrm{CH}$ strong stretch, 1959.5 and $1658.7 \mathrm{~cm}^{-1}$ corresponding to $\mathrm{C}=\mathrm{O}$ strong stretch, $1234.4 \mathrm{~cm}^{-1}$ corresponding to $\mathrm{CO}$ strong stretch and for compound 3 a wave numbers $3247.9 \mathrm{~cm}^{-1}$ corresponding to $\mathrm{NH}$ medium stretch, $2360.7 \mathrm{~cm}^{-1}$ corresponding to $\mathrm{C}-\mathrm{H}$ strong aromatics, $1658.7 \mathrm{~cm}^{-1}$ corresponding to $\mathrm{C}=\mathrm{N}, 1527.5 \mathrm{~cm}^{-1}$ corresponding to $\mathrm{C}=\mathrm{C}$ aromatic, $1450.4 \mathrm{~cm}^{-1}, 1357.8 \mathrm{~cm}^{-1}$ corresponding to the $\mathrm{C}-\mathrm{N}$, 1234.4, 1195.8 corresponding to C-O-C. The ${ }^{1} \mathrm{H}-\mathrm{NMR}$ Spectra were measured in dimethylsulfoxide- $\mathrm{d}_{6}$ for compounds $2 \mathrm{a}$ and $3 \mathrm{a} .{ }^{1} \mathrm{H}-\mathrm{NMR}$ Spectrum of compound $2 \mathrm{a}$ showed a characteristic signal at $\delta$ 7.3-7.6 ( $\mathrm{m}, 10 \mathrm{H}, \mathrm{Rah})$, 8.0 (bus, $\left.2 \mathrm{H}, \mathrm{NH}_{2}\right), 8.1(\mathrm{~s}, 2 \mathrm{H}, \mathrm{CH}$ ) and the compound 3 a showed a characteristic signal at $\delta 7.22-7.48(\mathrm{~m}, 10 \mathrm{H}$, Rah). 


\section{Screening of insecticidal activity}

Insecticides are those substances which kill insects by their chemical reaction, the effect of insecticidal activity on plant, animals or products in the open area to be treated by sprays or dusts. The larvae of Heliothis armigera were used to study the effect of toxicity by stomach poison and contact poisons. On screening of stomach poison of $\mathrm{N}^{\prime 1}, \mathrm{~N}^{\prime 2}$ - bis [(4-hydroxy-3-methoxyphenyl) methylidene] ethanedihydrazide (2d)and 5,5'-diphenyl-2, 2'-bi-1,3,4-oxadiazole (3a) showed 33.33 and 29.17\% of mortality while other compounds $\mathrm{N}^{\prime 1}, \mathrm{~N}^{\prime 2}$-bis[(2hydroxyphenyl) methylidene] ethanedihydrazide (2b), $\mathrm{N}^{\prime 1}, \mathrm{~N}^{\prime 2}$ - bis [(4-methoxyphenyl) methylidene] ethanedihydrazide (2c), 2,2'-(2, 2'-bi-1,3,4-oxadiazole-5, 5'-diyl) diphenol (3b), 4,4'-(2,2'-bi-1,3,4-oxadiazole-5,5'-diyl) bis (2-methoxyphenol) (3d) showed moderate mortality rate of $16.67,16.67,20.83$ and $16.67 \%$. The compounds $\mathrm{N}^{\prime 1}, \mathrm{~N}^{\prime 2}$-bis [phenylmethylidene] ethanedihydrazide (2a) and 5, 5'-bis (4-methoxyphenyl)-2, 2'-bi-1, 3, 4-oxadiazole (3c) exhibits low mortality of $12.50 \%$ each. In case of contact poison toxicity of $2 \mathrm{~b}, 2 \mathrm{c}$ and $2 \mathrm{~d}$ compounds showed high percentage of mortality i.e., $41.67,62.50$ and $70.83 \%$ while other compounds $2 \mathrm{a}, 3 \mathrm{a}, 3 \mathrm{~b}, 3 \mathrm{c}$ and $3 \mathrm{~d}$ showed moderated percentage of mortality i.e., 29.19, $24.17,20.83,20.83$ and $29.17 \%$, respectively when compare with standard and untreated control. The results are summarized in Table 2.

\section{Anti-bacterial activity}

The results of anti-bacterial activity study indicated that among the tested compounds 3(a) and 3(b) showed high activity against Kallipsi calla, whereas in case of Escherichia coli 2(d), 3(a), 3(c), 3(d) showed maximum activity, while other compounds 2(a), 2(b) and 2(c), showed moderate activity. The compounds were ineffective against Portious vulgaris as compared with the standard drug.

\section{Antifungal activity}

Among the synthesized compounds the anti-fungal activity of the compound 3(a) and 3(d) showed high activity against $A$. nigar 2(a), 2(c), 3(b) and 3(c) showed moderate results whereas 2(b) and 2(d) are inactive. In case of $A$. flavous 3(c) and 3(a) compounds showed maximum and average inhibition, the remaining compounds are inactive. All the compounds were moderately active against $C$. albicans while 2(c), 3(a) and $3(d)$ not shown any activity. The antibacterial and antifungal activity results are summarized in Table 3 .

\section{Anti-inflammatory activity}

Among all the compounds the 2(a), 2(b) and 3(c) have shown good anti-inflammatory activity whereas $2(\mathrm{~d})$

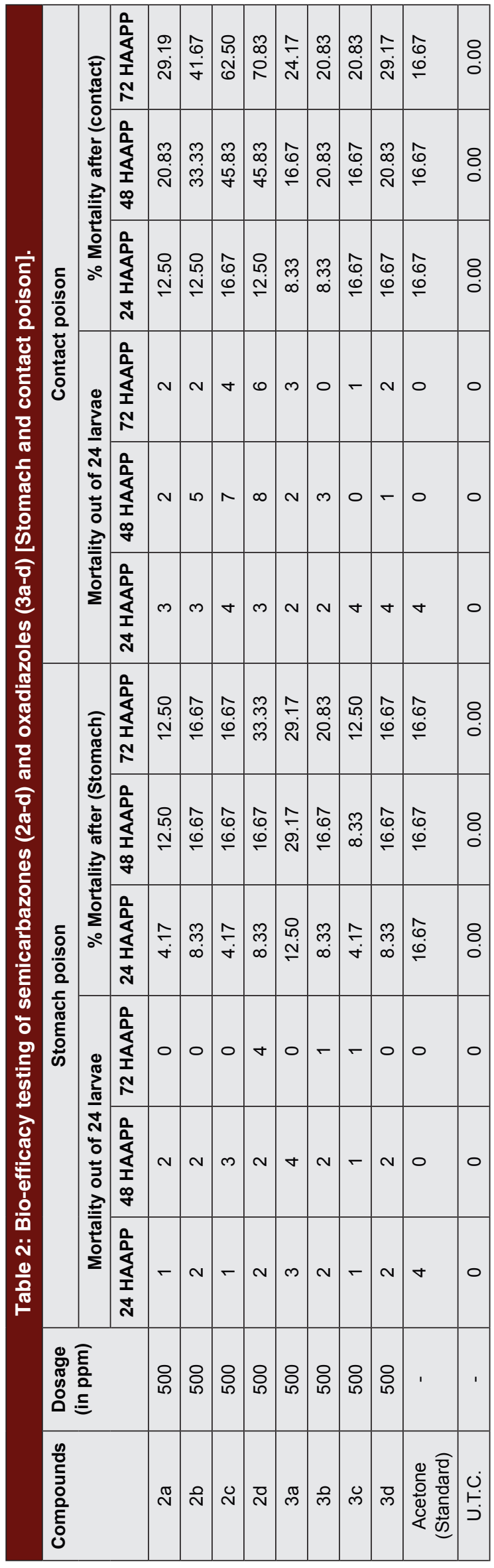


and 3(d) have shown moderate activity while 2(c), 3(a) and 3(b) compounds did not possess any activity. The results of anti-inflammatory activity of standard and samples are tabulated in Table 4

\section{Molecular Docking Studies}

Molecular docking simulation of 2a-d and 3a-d with Crystal Structure of Russell's viper Phospholipase A2 was performed to gain functional and structural insight into the mechanism of inhibition. AutoDock 4.2 suites were used as molecular-docking tool. For the in silico docking studies, semicarbazones and oxadiazole derivatives were docked against Phospholipase A2, using the co-crystallized ligand structure of Diclofenac as reference. Diclofenac was relocked to its active site to calculate the binding energy, inhibition constant using Auto Dock. The active

\begin{tabular}{|c|c|c|c|c|c|c|}
\hline \multirow[t]{2}{*}{ Compounds } & \multicolumn{3}{|c|}{ Anti-bacterial } & \multicolumn{3}{|c|}{ Antifungal Activity } \\
\hline & $\begin{array}{l}\text { Kallipsi calla ' } k \text { ' } \\
\quad \text { (in } \mathrm{mm} \text { ) }\end{array}$ & $\begin{array}{c}\text { Escherichia coli } \\
\text { 'EC' } \\
\text { (in } \mathrm{mm} \text { ) }\end{array}$ & $\begin{array}{c}\text { Portious vulgaris } \\
\text { 'PV' (in mm) }\end{array}$ & $\begin{array}{l}\text { A. niger 'AN' } \\
\text { (in } \mathrm{mm} \text { ) }\end{array}$ & $\begin{array}{l}\text { A. flavas 'AF' } \\
\text { (in } \mathrm{mm} \text { ) }\end{array}$ & $\begin{array}{l}\text { C. albicans ' } C A \text { ' } \\
\text { (in } \mathrm{mm} \text { ) }\end{array}$ \\
\hline $2 a$ & 10 & 09 & 08 & 09 & - & 09 \\
\hline $2 \mathrm{~b}$ & 10 & 08 & 09 & - & - & 08 \\
\hline $2 c$ & 10 & 10 & 09 & 07 & - & - \\
\hline $2 d$ & 10 & 12 & 08 & - & - & 08 \\
\hline $3 a$ & 14 & 15 & 09 & 10 & 08 & - \\
\hline $3 b$ & 15 & 10 & 07 & 08 & - & 06 \\
\hline $3 c$ & 12 & 15 & 10 & 09 & 12 & 07 \\
\hline $3 d$ & 13 & 12 & 08 & 12 & - & - \\
\hline Standard & 29 & 28 & 22 & - & - & - \\
\hline Control (DMSO) & 06 & 06 & 06 & - & - & - \\
\hline
\end{tabular}

\begin{tabular}{|c|c|c|c|c|c|c|}
\hline \multirow{2}{*}{ Group } & $\begin{array}{c}\text { Dose } \\
(\mathbf{m g} / \mathbf{k g})\end{array}$ & \multicolumn{5}{c|}{ Mean value of hind paw odema at different time of intervals in hours } \\
(mean 24 \pm SE)
\end{tabular}




\begin{tabular}{|c|c|c|c|c|}
\hline Protein name & Ligand structure & $\begin{array}{l}\text { Binding energy } \\
\text { (kcal } / \mathrm{mol})\end{array}$ & $\begin{array}{l}\text { Amino acids involved in } \\
\text { Hydrogen Bonding }\end{array}$ & $\begin{array}{l}\text { Predicted IC }{ }_{50} \text { (micro } \\
\text { molar) from AutoDock }\end{array}$ \\
\hline \multirow[t]{8}{*}{ Phospholipase A2 } & $2 a$ & -7.11 & Asp49 & 6.14 \\
\hline & $2 b$ & -7.69 & $\begin{array}{c}\text { Tyr28 } \\
\text { Gly30 } \\
\text { Trp31 } \\
\text { Asp49 }\end{array}$ & 2.33 \\
\hline & $2 c$ & -7.03 & $\begin{array}{l}\text { Leu2 } \\
\text { Gly30 }\end{array}$ & 7.04 \\
\hline & $2 d$ & -6.01 & $\begin{array}{l}\text { Leu2 } \\
\text { Gly30 } \\
\text { Asp49 }\end{array}$ & 39.2 \\
\hline & $3 a$ & -7.17 & $\begin{array}{l}\text { Gly30 } \\
\text { Asp49 }\end{array}$ & 5.59 \\
\hline & $3 b$ & -7.54 & $\begin{array}{l}\text { GLY30 } \\
\text { ASP49 } \\
\text { LYS69 }\end{array}$ & 2.95 \\
\hline & $3 c$ & -6.2 & - & 28.36 \\
\hline & $3 d$ & -7.78 & $\begin{array}{l}\text { Tyr22 } \\
\text { His48 } \\
\text { Asp22 }\end{array}$ & 2.00 \\
\hline Phospholipase A2 & Diclofenac(DIF) & -7.04 & $\begin{array}{l}\text { His } 48(A) \\
\text { Asp } 99(A)\end{array}$ & 6.9 \\
\hline
\end{tabular}

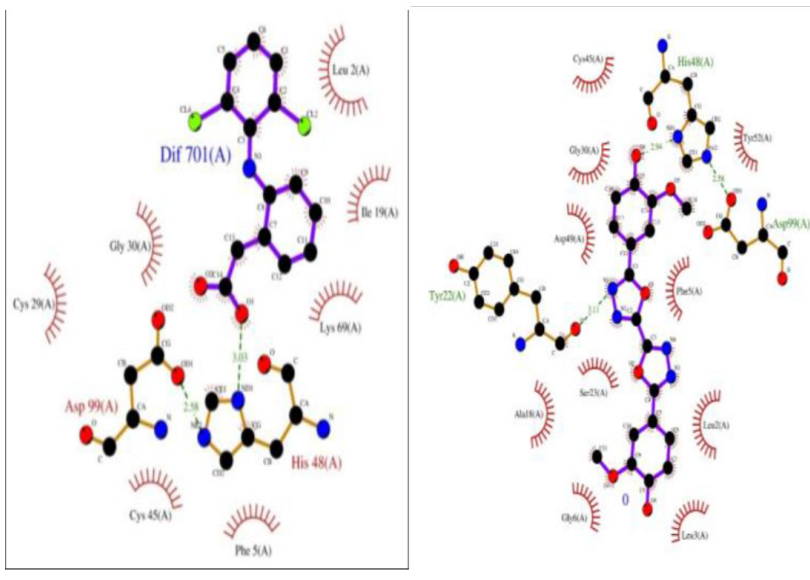

Figure 4: Molecular interaction of DIF and 3d with Phospholipase A2 from Ligplot+.

(A) Molecular interaction of DIF with Phospholipase A2 as represented in PDBsum (PDB: 2B17)

(B) Molecular docking interaction of 3d with Phospholipase A2.

site comprises of Leu2, Phe5, Ile19, Cys29, Gly30, Cys45, His48, Lys69 and Asp99. The semicarbazones and oxadiazole derivatives were allowed to dock at the active site with the complete flexibility. The best pose having least binding energy revealed the electrostatic interaction and hydrogen bonding which facilitate the binding to the active site. The experimental results of interaction of Diclofenac (PDB: 2B17) with Phospholipase A2 shows that the $K_{i}=6.9 \mu \mathrm{M}$ by forming hydrogen bonds with His 48and Asp99. The interaction of $3 \mathrm{~d}$ with
PAP2 (PDB: 2B17) shows three hydrogen bonds with active site residues Tyr22, His 48 and Asp99. The $\mathrm{K}_{\mathrm{i}}$ of 2.0 $\mu \mathrm{M}$ was observed which is low as compare to standard drug Diclofenac. $\mathrm{IC}_{50}$ values of declofenac and semicarbazones derivatives were predicted from AutoDock. Based on very low binding energy of $-7.78 \mathrm{kcal} / \mathrm{mol}$ and low $\mathrm{IC}_{50}$ of $2.0 \mu \mathrm{M}$, the 3(d) proves to be a competitive inhibitor as compared to Diclofenac and as a potential anti-inflammatory lead molecule since the ligand interact with a relatively higher affinity and lower inhibition constant than the standard diclofenac. PLA2 catalyzes the calcium-dependent hydrolysis of the 2-acyl groups in 3-sn-phosphoglycerides. The cofactor calcium uses the metal binding residues Tyr27, Gly29, Gly31 and Asp48 (residue numbering according to PDB) via carbonyl oxygen for its activity. Compound $3 \mathrm{~d}$ formed hydrogen bond with these metal binding residues and blocked the interaction of calcium and further disturbs the hydrolysis and inactivates the enzyme. Compound $3 \mathrm{~d}$ formed Binding energy and inhibition constant of all the docked compounds including both the standard drugs were presented in Table 5 and supported by enclosing Figure 4.

\section{CONCLUSION}

The novel series of semicarbazones and oxadiazoles were synthesized in reasonably good yields. The outcome from this study clearly showed that the chemical 
structures were found to be in accordance with their IR and ${ }^{1} \mathrm{H}-\mathrm{NMR}$ Spectra. The synthesized compounds were assessed for insecticidal activity, anti-bacterial, anti-fungal, anti-inflammatory potentials.

The Compound 2(d) and 3(a) shows high percentage of mortality compared to standard acetone. The increased percentage of mortality of compound may be due to the very low binding energy and presence of substituent. Other compounds show moderated and less mortality because of moderately high binding energy. The Compounds 3(a) and 3(b) showed high activity against Kallipsi calla and Escherichia coli as compared to standard. The compounds 3(a) and 3(d) showed high activity against $A$. nigar and in case of $A$. flavous 3(c) and 3(a) compounds showed maximum inhibition. Compounds 2(a), 2(b) and 3(c) have shown good antiinflammatory activity when compared with the standard diclophenac sodium. The molecular docking studies of the synthesized compounds were performed. The Compound 3(d) proves to be a competitive inhibitor as compared to Diclofenac and as a potential antiinflammatory lead molecule since the ligand interact with a relatively higher affinity and lower inhibition constant. Compound 3(d) showed the least binding energy which is in agreement with the in vitro results. Hence, this study has extended the scope of developing these semicarbazones and oxadiazole derivative as positive antimicrobial agents.

\section{ACKNOWLEDGEMENT}

We extend our special thanks to Dr. M. G. Purohit. Professor of Organic Chemistry, Department of Chemistry, Gulbarga University, Gulbarga for providing facilities in animal experimentation techniques / procedures and to Dr. Suhas Yelshetty, Scientist (Entomology). Agricultural Research Station, Gulbarga for his timely help in screening the synthesized compounds for insecticidal activity at Agricultural Research Station, Gulbarga. The authors express deep sense of gratitude and indebtedness to Dr. Somanth V. Patil for valuable suggestions and encouragement throughout the project work. Authors acknowledge the funding agencies VTU Belagavi, AICTE New Delhi and VGST-KFIST (L1) / GDR580/2016-17 for their financial support.

\section{CONFLICT OF INTEREST}

The authors declare that they have no conflict of interests.

\section{ABBREVIATIONS}

HCl: Hydrochloric acid; KBr: Potassium bromide; $\mathbf{N a O H}$ : Sodium hydroxide; DCC: 1,3- dicyclohexylcarbodimide; $\mathbf{H g}$ (OAc): Mercury (II) acetate; $\mathbf{H g O}$ : Mercury (II) oxide; TMS: Tetramethylsilane; TLC: Thin layer chromatography; DMSO-d $\mathbf{d}_{6}$ : Dimethyl sulfoxide- $\mathrm{d}_{6}$; AR: Analytical Reagents; DMF: Dimethylformamide.

\section{REFERENCES}

1. Pavithra G, Ajay KK. Design, synthesis and biological evaluation of 1,3 , 4-oxadiazoles / thiadiazoles bearing pyrazole scaffold as antimicrobial and antioxidant candidates. Current Chemistry Letters. 2016;5(3):109-22.

2. Mohamed NI, Al-Difar HA. Synthesis and anti-bacterial activity of semicarbazone derivatives of some carbonyl compounds. Pelagia Research Library: Der Chemica Sinica. 2011;2(1):171-3.

3. Rajak H. Synthesis and evaluation of some novel semicarbazones based benzimidazole derivatives as anticonvulsant agent. International Journal of Chemical Engineering and Applications. 2015;6(2):142-5.

4. Davinder P, Nisha A, Rajesh K, Mahendra N. Synthesis of novel hetroareans based [1, 2, 3]-triazoles via click chemistry and their evaluation for antibacterial activity. Indian Journal Chemistry. 2012;51:731-8.

5. Jianming X, Yongbing C, Zhang J, Shichong Y, Yan Z, Xiaoyun C, et al. Design synthesis and antifungal activities of novel 1, 2, 4- triazole derivatives. European J Med Chem. 2011;46(7):3142-8.

6. Zahra R, Soghra K, Keyvan P, Zahra H, Fatemeh A, Elham A, et al. Design, synthesis and antifungal activity of triazole and benzotriazolederivatives. European J Med Chem. 2009;44(7):3064-7.

7. Frank W, Xinli T, Torsten K, Jens P, Mavanur S. Synthesis and cyclooxygenase inhibition of various (aryl-1, 2, 3- triazole-1-yl)-methanesulfonylphenyl derivatives. Bioorganic and Medicinal Chemistry. 2009;17(3):1146-51.

8. Sanjeev K. Synthesis and biological activity of 5-substituted-2-amino-1, 3, 4oxadiazole derivatives. Turk J Chem. 2011;35(1):99-108.

9. Yogesh $M$, Devender P. Design, synthesis and biological evaluation of some novel 2, 5-disubstituted-1, 3, 4-oxadiazole derivatives. International Journal of Drug Design and Discovery. 2011;2:659-65.

10. Kumar S, Srivastava DP. Efficient electrochemical synthesis, antimicrobial and anti-inflammatory activity of 2-amino-5-substituted- 1, 3, 4-oxadiazole derivatives. Indian J Pharm Sci. 2010;72(4):458- 64.

11. Robert MS, Clayton BG, Terence CM. Spectrometric identification of organic compounds. Wiley Publishe. 1981

12. Giri SK. K. M. Sc. Dissertation, Gulbarga University, Gulbarga. 2001.

13. Cruinckshank R, Duguid JP, Marmion BP, Swain RHA. Medical Microbiology, London, Churchill Livingstone. 1975;196.

14. Aalten DMFV, Bywater R, Findlay JBC, Hendlich M, Hooft RWW, Vriend G, et al. A program for generating molecular topologies and unique molecular descriptors from coordinates of small molecules. Journal of Computer -Aided Molecular Design. 1996;10(3):255-62.

15. Wolf LK. New software and websites for the chemical enterprise. Chemical and Engineering News. 2009;87(45):31.

16. Garrett MM, David SG, Robert SH, Ruth H, William EH, Richard KB, et al. Automated Docking using a Lamarckian Genetic Algorithm and an Empirical Binding Free Energy Function. Journal of Computational Chemistry. 1998;19(14):1639-62.

17. Wallace AC, Laskowski RA. LIGPLOT: A program to generate schematic diagrams of Protein-ligand interactions. Protein Eng.1995;8(2):127-34.

18. Delano WL. The Pymol Molecular Graphics System DeLano Scientific, San Carlos, CA USA. 2002. 


\section{PICTORIAL ABSTRACT}

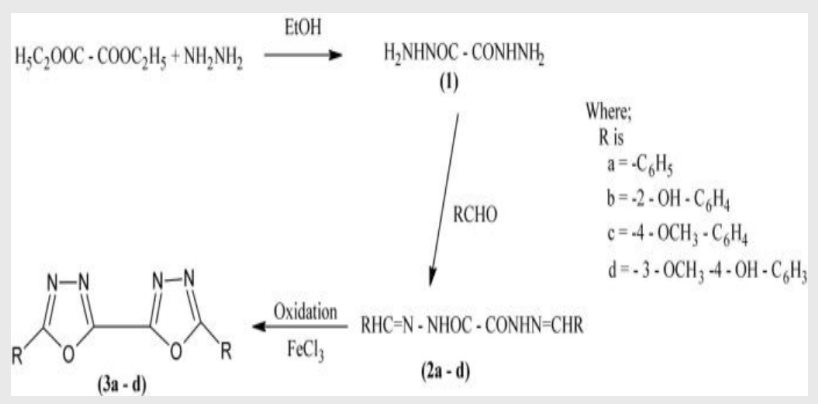

The novel series of semicarbazones (2a-d) and oxadiazoles (3a-d) were synthesized in reasonably good yields. The synthesized compounds were in noble arrangement with elemental and spectral data. The synthesized compounds were assessed for insecticidal activity, anti-bacterial, anti-fungal, anti-inflammatory potentials and molecular docking studies.

\section{SUMMARY}

- A series of novel substituted semicarbzones and oxadiazoles were synthesized in reasonably good yield. Chemical structures were characterized and are in accordance with their IR and ${ }^{1} \mathrm{H}-\mathrm{NMR}$ spectra. Obtained compounds were subjected for insecticidal activity and pharmacological screening viz, anti-bacterial, anti-fungal, anti-inflammatory potentials and molecular docking studies.

- Majority of the synthesized compounds exhibits potential inhibition while few of them exhibits moderate activity. The docking studies for semicarbzones and oxadiazoles derivatives were against Phospholipase A2, using the co-crystallized ligand structure Diclofenac as reference. The compound formed binding energy and inhibition constant of all the docked compounds including both the standard drugs showed the least binding energy which is in agreement with the in vitro results.

\section{About Authors}

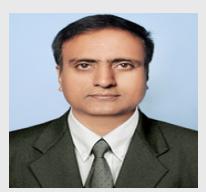

Dr. Veerabhadraswamy Mruthyunjaya, Assistant Professor of Chemistry, PES University, Bengaluru, India working since 2009, is a post doctoral fellow from Queens University Belfast, Belfast, Northern Ireland UK, presently engaged in green chemistry and green engineering education promotion in India through design and develop learning model to suite Indian education system. His current research interests are conversion of biomass into bio-platform molecules, green synthesis of value added chemicals from renewable resources. He is active member steering the Green Chemistry Centre at PE S University aims to develop, execution of green and sustainable chemistry, fuse allied technologies into new products and process. Networking both with academia and industry as well as conducting awareness programs for common people.

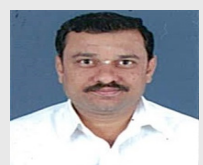

Mr. Bhimashankar B Molkere is a Research Fellow at PES University, Bengaluru, Karnataka, India presently working in the field of green synthesis of compounds having high value products employing novel greener techniques. His focus is to design, develop and synthesis semicarbazones, oxadiazoles and triazoles.

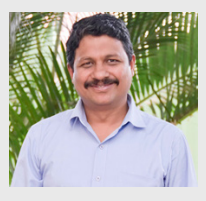

Dr. Prashantha Karunakar is an Assistant Professor at PES University Bengaluru, Karnataka, India since 2011. He worked at synchrotron facilities like DESY, Hamburg, Germany and ESRF, Grenoble, France. His research interest involves Crystallography, Bioinformatics, Computational Biology, Computational Chemistry and Molecular Docking and Dynamics Simulations.

Cite this article: Veerabhadraswamy M, Molkere BB, Karunakar P. Synthesis and Evaluation of Insecticidal Activity of Bis-Semicarbazones and Bis-(5-Aryl Substituted-1, 3, 4-Oxadiazole). Indian J of Pharmaceutical Education and Research. 2019;53(3 Suppl 2):s423-s432. 